\title{
ЗАХОДИ ПІДТРИМКИ ВІДНОВЛЮВАНОЇ ЕНЕРГЕТИКИ В УКРАЇНІ
}

В.А. Хілько, науковий співробітник

Інститут відновлюваної енергетики НАН України,

02094, вул. Гната Хоткевича, 20А, м. Київ, Україна.

Мета статті - визначення заходів зі сприяння розвитку відновлюваної енергетики в Украӥні. Надано послідовність створення пільгових ставок тарифів на електроенергію ВДЕ відповідно до законодавства України. Необхідно прийняти до уваги, що Закон Украӥни «Про альтернативні джерела енергї» є базовим механізмом підтримки системи «зелених» тарифів. Держава зобов'язується викуповувати всю вироблену за проєктами ВДЕ електроенергію за фіксованим тарифом, яка в Україні до того ж прив'язана до євро. Отже, інвестор у відновлюваній енергетиці може побудувати надійну фінансову модель проєкту й бути впевненим у поверненні своїх інвестицій упродовж тривалого строку діяльності. В статті обтрунтовано впровадження системи «зелених» аукиіонів як державної схеми підтримки проєктів ВДЕ замість донедавніх «зелених» тарифів. Аукціони дозволяють залучати приватні інвестииії (вітчизняні та іноземні) за допомогою чітких та прозорих процесів. Визначено функиії державного підприємства для виконання гарантованої закупівлі електроенергї з ВДЕ згідно з ринковими умовами в Україні. Надано основні організаційні переваги участі інвесторів у системі «зелених» аукиіонів. Напрямком прийнятого у 2020 роиі Закону Украйни N 810-ІХ є зменшення ставок «зелених» тарифів, щуо ставить під загрозу перехід країни до сталого розвитку та виконання нею своӥх міжнародних зобов 'язань. Дія зазначеного Закону призводить до відтермінування будівництва за багатьма новими проєктами. Незважаючи на це, системи «зелених» тарифів та «зелених» аукиіонів залитаються в країні основною формою держсавної підтримки відновлюваної енергетики. Наразі, за результатами державної підтримки, встановлена потужність об'єктів генераиї̈ на відновлюваних джерелах енергії становить близько 8700 МВт. Ними за квітень 2021 року вироблено 1020 млн кВт-г електроенергії, щуо складає 8,3 \% обсягу споживання електроенергї в Україні. В украӥнській енергосистемі вже зафіксовані випадки, коли за добу з відновлюваних джерел (включно із великими ГЕС) було вироблено більше електричної енергї, ніж усіма тепловими електростаниіями $i$ теплоелектрочентралями України разом узятими. Бібл. 11, табл. 1, рис. 5.

Ключові слова: відновлювані джерела енергї, відновлювана енергетика, пільговий тариф, ринок електричної енергії, система аукиіонів, аукціонна ціна, квота підтримки, ставки «зелених» тарифів, перспективні механізми підтримки.

\section{MEASURES TO SUPPORT RENEWABLE ENERGY IN UKRAINE}

V. Khilko, research officer

Institute of Renewable Energy of the National Academy of Sciences of Ukraine, 02094, 20A Hnata Khotkevycha St., Kyiv, Ukraine.

The purpose of the article is to identify measures to promote the development of renewable energy in Ukraine. The sequence of creation of preferential rates of tariffs for electricity RES according to the legislation of Ukraine is given. It should be taken into account that the Law of Ukraine "On Alternative Energy Sources" is a basic mechanism for supporting the system of "green" tariffs. The state undertakes to purchase all electricity produced by RES projects at a fixed rate, which in Ukraine is also pegged to the euro. Thus, an investor in renewable energy can build a sound financial model of the project and be confident in the return on their investment over the long term. The article substantiates the introduction of a system of "green" auctions as a state scheme of support for RES projects instead of the existing "green" tariffs. Auctions allow you to attract private investment (domestic and foreign) through clear and transparent processes. The functions of the state enterprise for performance of the guaranteed purchase of the electric power from RES according to market conditions in Ukraine are defined. The main organizational advantages of investor participation in the system of "green" auctions are given. The direction of the Law of Ukraine N 810-IX adopted in 2020 is to reduce the rates of "green" tariffs, which threatens the country's transition to sustainable development and fulfillment of its international obligations. The action of this 
Law postpones the construction of most of the new projects. Despite this, systems of "green" tariffs and "green" auctions remain the main form of state support for renewable energy in the country. Currently, according to the results of state support, the installed capacity of generating facilities on renewable energy sources is about 8700 MW. In April 2021, they generated 1020 million kWh of electricity, which is 8.3 percent of Ukraine's electricity consumption. The Ukrainian power system has already recorded cases when more electricity was generated per day from renewable sources (including large hydropower plants) than from all thermal power plants and thermal power plants in Ukraine combined. Ref. 11, tabl. 1, fig. 5.

Keywords: renewable energy sources, renewable energy, preferential tariff, electricity market, auction system, auction price, support quota, green tariff rates, promising support mechanisms.

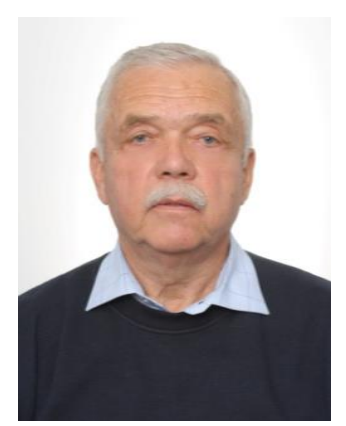

B.A. Хілько

V. Khilko
Відомості про автора: науковий співробітник Інституту відновлюваної енергетики НАН України

Освіта: Київський технологічний інститут легкої промисловості, факультет електротехніки та автоматики

Наукова сфера: відновлювана енергетика, економічний аналіз, електропостачання

Публікації: 39 публікацій

ORCID: 0000-0001-6348-2578

Контакти: +38(050)410-58-92

e-mail: vladimirkhilko@gmail.com
Author information: Research officer of the Institute of Renewable Energy of the NAS of Ukraine

Education: Kyiv's Technological Institute of Light Industry on Electrical Engineering and Automatics Faculty

Research area: renewable energy, economic analysis, power supply

Publications: 39 publications

ORCID: 0000-0001-6348-2578

Contacts: +38 (050) 410-58-92

e-mail: vladimirkhilko@gmail.com

Перелік використаних позначень та скорочень:

НАН - Національна академія наук;

ВДЕ - відновлювані джерела енергії;

ПДВ - податок на додану вартість;

ДП - державне підприємство;

НКРЕКП - Національна комісія, що здійснює державне регулювання у сферах енергетики та комунальних послуг;

УВЕА - Українська вітроенергетична асоціація;
Pre-PРA - (англ. Pay Per Action) попередня угода купівлі електроенергії;

ГЕС - гідравлічна електрична станція;

CEC - сонячна електрична станція;

ВEC - вітряна електрична станція;

Мінпаливенерго - Міністерство енергетики та вугільної промисловості України.
Вступ. Широкомасштабне впровадження найбільш економічно доцільних джерел енергії, де пріоритетне місце в Україні посідають відновлювані джерела енергії, має на меті диверсифікацію ресурсів та повне забезпечення потреб держави в енергії власного виробництва. Відновлювана енергетика сприяє енергетичній незалежності держави, яка $є$ складовою національної безпеки. 3 метою підтримки відновлюваної енергетики держава робить рішучі кроки у напрямку створення сприятливих умов для іiі розвитку.
На початку 90-х років Постановою Кабінету Міністрів України № 415 від 15 червня 1994 р. вперше було надано державне фіксування розвитку вітроенергетики. В подальшому Указом Президента України № 159 від 2 березня 1996 року було визначено розмір коштів до 0,75\% обсягу товарної продукції виробництва електроенергії з їх спрямуванням на будівництво вітрових електричних станцій (ВЕС).

Постановою Кабінету Міністрів України № 137 від 3 лютого 1997 р. було затверджено Комплексну програму будівництва вітрових 
електростанцій, фінансування якої здійснювалось за рахунок коштів, визначених вказаним вище Указом Президента України.

Постановою Кабінету Міністрів України № 1505 від 31 грудня 1997 р. було схвалено Програму державної підтримки розвитку нетрадиційних та відновлюваних джерел енергії та малої гідро- і теплоенергетики, як складову частину Національної енергетичної програми України. Передбачено щорічно виділяти кошти для виконання зазначеної Програми в межах видатків, визначених для фінансування Національної енергетичної програми України.

3 метою наукового-технічного супроводу Комплексної програми у 2000 році було створено державне підприємство Міжгалузевий науковотехнічний центр вітроенергетики, підпорядкований Національній академії наук України. Його основним завданням була наукова, технічна та організаційна підтримка будівництва та експлуатації ВЕС в Україні.

В результаті реалізації Комплексної програми будівництва вітрових електростанцій в Україні була створена галузь вітроенергетики. Велось будівництво 13 вітрових електростанцій в системі Мінпаливенерго, Держводгоспу, Міноборони та інших. Також була виконана розробка пакету нормативних $\mathrm{i}$ технічних документів у сфері відновлюваної енергетики, зокрема проведена гармонізація ряду зарубіжних стандартів.

Досвід, набутий за зазначеною Комплексною програмою у виконанні науководослідних робіт в будівництві та промисловій експлуатації електричних станцій, надалі забезпечив масштабний розвиток відновлюваної енергетики України.

\section{Хронологія впровадження пільгових} ставок тарифів на електроенергію ВДЕ. У першій редакції Закону України «Про альтернативні джерела енергії», який був прийнятий у 2003 році (Відомості Верховної Ради України, 2003, № 24, ст. 155), визначено стимулювання виробництва та споживання енергії, виробленої з ВДЕ. В поточній редакції Закону від 16.10 .2020 [1] встановлюються спеціальні пільгові так звані зелені ставки тарифів, відповідно до яких закуповується електрична енергія, вироблена на об'єктах електроенергетики з ВДЕ.

\section{Історія впровадження «зеленого» тарифу}

в Україні. Першим впровадженням «зеленого» тарифу в країні був Закон України № 601-VI «Про внесення змін до деяких законів України щодо встановлення «зеленого» тарифу» [2], який був прийнятий 25 вересня 2008 року. За цим Законом встановлюється дія «зеленого» тарифу для суб'єктів господарської діяльності, які виробляють електричну енергію з альтернативних джерел енергії. Також більш чітко був визначений термін «альтернативні джерела енергії». Відповідно до цього Закону, його дія розповсюджується на відновлювані джерела енергії, до яких належать енергія сонячного сяйва, вітрова, геотермальна, гідроенергія та інші.

По суті, у 2009 році законодавством 3 підтримки проектів «зеленої» енергетики були передбачені надвисокі тарифи на енергію, вироблену на великих сонячних станціях, звільнення від податку на прибуток до 2020 року та від сплати ПДВ під час ввезення профільного обладнання і матеріалів. Доступ на ринок був обмежений введенням вимоги щодо «місцевої складової» - питомої ваги сировини і матеріалів 
українського походження у вартості будівництва об'єкта ВДЕ.

У 2015 році були законодавчо ухвалені зміни [3], що збалансували утворення тарифів у сфері ВДЕ та створили можливості для іï швидкого розвитку. Вимогу щодо «місцевої складової» змінили на надбавки до тарифів, знизили надмірно високий тариф для великих сонячних проєктів. Також почала діяти норма закону про «зелений» тариф для приватних домогосподарств. Вона дала змогу інвестувати у сонячну енергію не тільки великим компаніям, а й окремим громадянам.

Створення ринкових умов закупівлі електричної енергії ВДЕ. У 2017 році був прийнятий Закон «Про ринок електричної енергії» [4]. Для створення умов 3 впровадження нової моделі ринку ухвалено декілька нормативноправових актів. За цим Законом Кабінет Міністрів України визначає державне підприємство для виконання функцій гарантованого покупця електричної енергії.

Державне підприємство «Гарантований покупець» зобов'язане:

- Купувати у виробників всю відпущену електричну енергію, за встановленим їм «зеленим» тарифом 3 урахуванням надбавки до нього.

- Купувати у виробників, які за результатами аукціону набули право на підтримку, всю відпущену електричну енергію за аукціонною ціною з урахуванням надбавки до неї. - Стати стороною, відповідальною за баланс балансуючої групи гарантованого покупця, до складу якої входять виробники, яким встановлено «зелений» тариф.

Система аукціонів. У 2019 році Законом України «Про внесення змін до деяких законів України щодо забезпечення конкурентних умов виробництва електричної енергії 3 альтернативних джерел енергії» [5] вводиться система аукціонів, як процедура державної підтримки виробників електричної енергії 3 відновлюваних джерел енергії на конкурентних засадах.

Аукціон 3 розподілу квоти підтримки (аукціон) - спосіб визначення суб'єктів господарювання, які набувають право на підтримку у виробництві електричної енергії 3 ВДЕ. Квотою підтримки виробників електричної енергії встановлюється обсяг потужності цих об'єктів електроенергетики.

Порядок купівлі-продажу ДП «Гарантований покупець» електричної енергії у виробників, які за результатами аукціону набули право на підтримку, визначений Постановою НКРЕКП № 641 від 26.04.2019 [6].

Перелік законодавчих актів щодо квот підтримки надано на рис. 1 (Джерело: Мінпаливенерго України). 


\section{Проведення «зелених» аукціонів та затвердження річних квот підтримки} передбачено низкою законодавчих актів

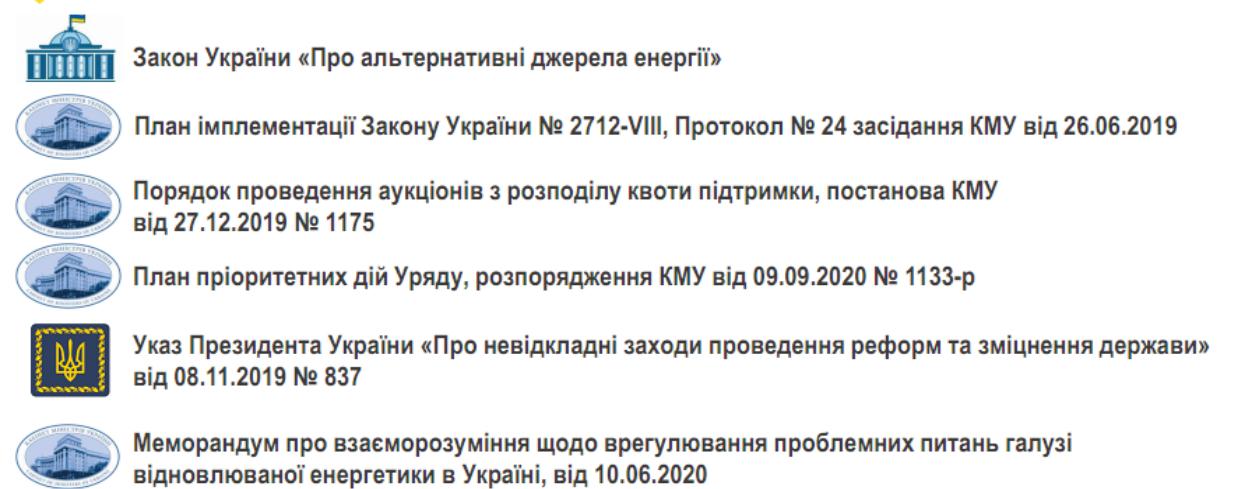

Рис. 1. Перелік законодавчих актів щодо квот підтримки ВДЕ

Fig. 1. List of legislative acts on RES support quotas

Механізм, заснований на конкуренції, такий як «зелений» аукціон, надає можливість виявити реальні ціни, особливо коли існує невизначеність щодо того, як оцінювати генерацію на основі ВДЕ. Ця якість зробила аукціони у світі одним 3 найбільш широко розповсюджених інструментів енергетичного переходу, навіть у країнах без попереднього досвіду механізмів підтримки відновлюваних джерел енергії.

Аукціонна ціна фіксується в євро за курсом Національного банку України на дату проведення аукціону. Існуюча система підтримки «зеленими» тарифами діятиме поруч 3 системою аукціонів. «Зелені» тарифи будуть діяти до 2030 року, але $з$ обмеженнями і тільки на вказані нижче суб'єкти господарювання:

-введені в експлуатацію до кінця 2019 року;

-введені в експлуатацію після 2019 року, які не підпадають під дію аукціонів;

-об'єкти, які до 31 грудня 2019 року вже отримали необхідні дозвільні документи на будівництво і щодо яких 3 ДП «Гарантований покупець» були укладені договори про покупку електроенергії, так звані pre-PРA;

-енергетичні кооперативи, приватні домогосподарства, генерувальні установки яких виробляють електричну енергію з ВДЕ в обсягах, що перевищують їх власне споживання.

Якщо об'єкти ВДЕ належать до учасників аукціонів, то «зелений» тариф таким суб’єктам господарювання отримати не можна.

\section{Оновлені умови роботи суб'сктів}

господарювання ВДЕ. Суб'єкти господарювання зобов'язані брати участь в аукціонах, якщо їх встановлена потужність становить:

-для об'єктів, що виробляють електричну енергію $з$ енергії вітру, - більше 5 МВт;

-для об’єктів, що виробляють електричну енергію з енергії сонячного випромінювання, більше 1 МВт.

Інші суб'єкти господарювання, які виробляють електричну енергію з ВДЕ (малі ГЕС, біоенергетика та інші) залишаються в системі «зелених» тарифів, але в перспективі можуть брати участь в аукціонах на добровільних засадах.

Не можуть брати участі в аукціонах суб'єкти господарювання, яким раніше було встановлено «зелений» тариф або надано право на підтримку за результатами аукціону.

Цінова пропозиція учасника, який бере участь в аукціоні для набуття права на підтримку об'єктів електроенергетики, що виробляють 
електричну енергію з ВДЕ, не може бути вищою за рівень «зеленого» тарифу для відповідної категоріï.

Нове законодавство а Україні дає інвестору дві незаперечні переваги. Перша перевага термін гарантованого державою викупу електроенергіï становитиме 20 років із прив'язкою до євро. Це на 10 років довше терміну дії «зеленого» тарифу, який діє до 2030 року. Цього періоду вистачає не лише для того, щоб повернути інвестиції, а й одержати дохід. Друга перевага - інвестор отримує державні гарантії

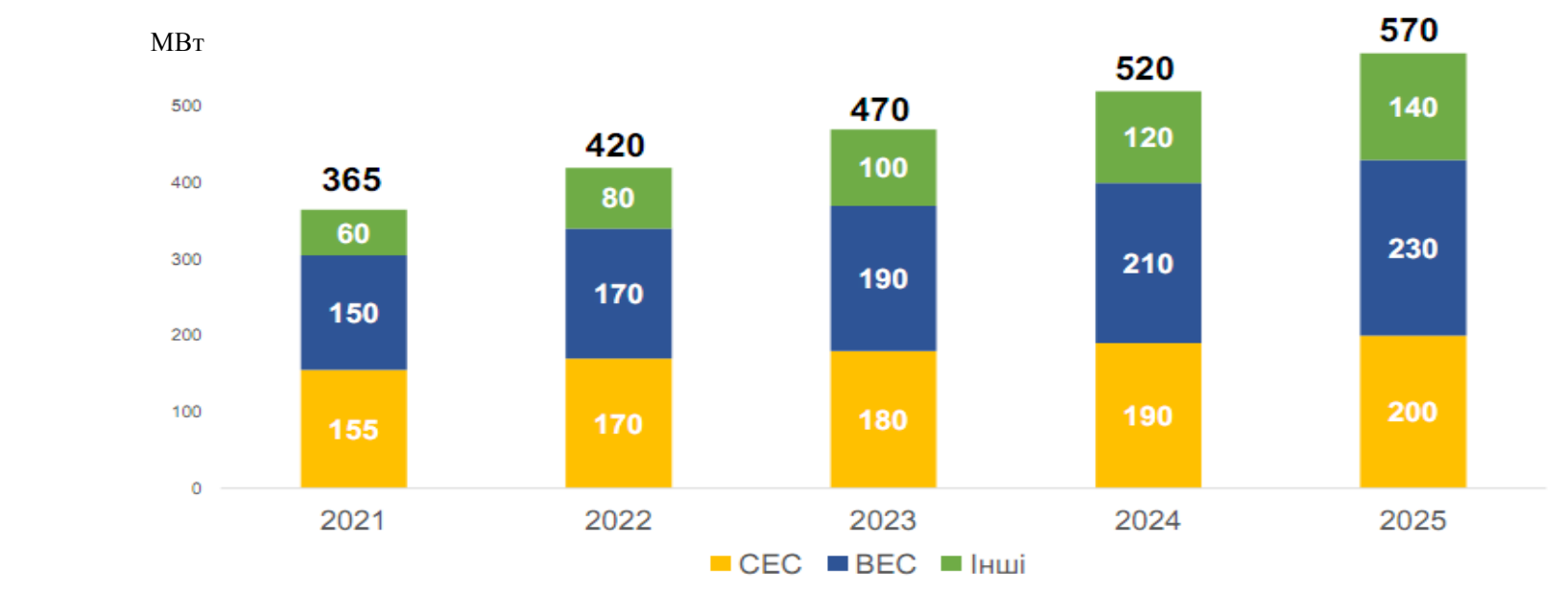

викупу електроенергії за аукціонною ціною до початку будівництва об'єкта, який претендує на підтримку держави, а не як у випадку 3 отриманням «зеленого» тарифу - після закінчення будівництва об'єкта.

Наприкінці 2020 року Міністерство енергетики України презентувало проєкт квот підтримки виробництва електричної енергії 3 відновлюваних джерел, індикативні прогнозні показники річних квот підтримки на 2022-2025 роки та графік проведення аукціонів на 2021 рік (див. рис. 2 та рис. 3).

Джерело: Міністерство енергетики Украӥни

Рис. 2. Проскт Міненерго річних квот підтримки на 2021 рік та індикативні прогнозні показники до 2025 року

Fig. 2. Draft Ministry of Energy annual support quotas for 2021 and indicative forecast indicators until 2025

\begin{tabular}{|c|c|c|c|c|c|c|c|c|c|c|c|c|c|}
\hline Вид & Тип & Сі4. & Лют. & Eep. & Kвir. & Черв. & Лип. & Cep. & Bep. & Жовт. & Лист. & Груд. & Bcboro \\
\hline \multirow{3}{*}{ CEC } & Загальний & & & & & 50 & & & & & 50 & & 100 \\
\hline & до $1 \mathrm{MBT}^{* *}$ & & & & & & & & & 5 & & & 5 \\
\hline & Регіональний & & & & & & & & & 50 & & & 50 \\
\hline BEC & Загальний & & & & & 50 & & & & & 100 & & 150 \\
\hline Інші & Загальний ${ }^{* * * *}$ & & & & & & & & & 60 & & & 60 \\
\hline & & & & & & $100^{*}$ & & & & 115 & 150 & & 365 \\
\hline
\end{tabular}

* Перші (пілотні) аукціони, ознайомлення інвесторів з процедурою їх проведення.

** Сприяння розвитку малої розподіленої генерації СЕС. Встановлена потужність СЕС до 1 МВт - 152 МВт. Кількість об'єктів 394. Середня потужність об'єкту 0,38 МВт.

*** Окремий аукціон в енергодефіцитних регіонах: Житомирській, Полтавській, Харківській, Чернігівській, Сумській, Черкаській, Кіровоградській, Київській областях та у м. Києві.

Джерело: Міністерство енергетики Украӥни

Рис. 3. Графік проведення аукціонів на 2021 рік

Fig. 3. Auction schedule for 2021 
Наразі ситуація дещо змінилася. За році та пізніше, додатково знижені ще на 2,5\%. повідомленням голови правління Української вітроенергетичної асоціації [7] Міністерство енергетики на нараді, яка відбулася 16 червня 2021 року, орієнтує представників галузі «зеленої» енергетики на проведення повноцінних «зелених» аукціонів в 2022 році, попередньо анонсувавши перегляд квот для різних типів ВДЕ. У 2021 році планується провести так званий пілотний аукціон на невелику потужність для відпрацювання процедури проведення аукціонів.

Зміни умов підтримки відновлюваної енергетики. Закон України № 810-IX «Про внесення змін до деяких законів України щодо удосконалення умов підтримки виробництва електричної енергії 3 альтернативних джерел енергії» [8] був прийнятий 21.07.2020 на виконання зобов'язань Кабінету Міністрів України та НКРЕКП перед виробниками електроенергії з відновлюваних джерел згідно 3 Меморандумом від 10 червня 2020 року, який спрямований на подолання поточної кризової ситуації на ринку електроенергії.

Законом № 810-IX зменшені тарифи для об'єктів, введених в експлуатацію з 1 липня 2015 до 31 грудня 2019 року:

-для сонячних електростанцій потужністю понад 1 МВт - на $15 \%$,

-для сонячних та вітрових електростанцій 3 потужністю менш як $1 \mathrm{MBT}-$ на 7,5\%.

Передбачений також i граничний рівень «зеленого» тарифу для відносно «старих» об'єктів відновлюваної енергетики. Для об’єктів ВДЕ, введених в експлуатацію до 30 червня 2015 року, встановлюється граничний (максимальний) «зелений» тариф у розмірі 24,56 євроцентів/кВт-г.

Ставки «зелених» тарифів для виробників на CEC та ВEC, введених в експлуатацію в 2020 При цьому закон не передбачає пролонгації дії старих тарифів, як це пропонували інвестори в «зелену» енергетику.

Крім того, зміни передбачають, що відтепер «зелені» виробники відповідатимуть за так званий небаланс. Тобто невідповідність планового та реального обсягу виробництва енергії з ВДЕ, що змушує оператора ринку включати в дію «балансуючі» потужності, коли «зелені» виробники не можуть постачити на ринок запланований обсяг енергії.

Позитивною стороною Закону № 810-IX є надання надбавки до «зеленого» тарифу та ціни, визначеної за результатами «зеленого» аукціону (аукціонної ціни), у разі використання обладнання українського виробництва на об'єктах електростанцій ВДЕ, які введені в експлуатацію 3 1 липня 2015 року до 31 грудня 2024 року. Закон також запроваджує поняття «зеленої металургії», - модернізовані і «чисті» підприємства не платитимуть «Укренерго» компенсацію за передачу «зеленої» електроенергії.

Разом 3 тим, для вирішення поточної кризи в енергетиці одного такого Закону явно недостатньо, оскільки криза викликана не тільки виробниками електричної енергії з ВДЕ, а цілим комплексом проблем в галузі. Останнім часом в Україні спостерігається загрозлива тенденція зниження сприяння «зеленій» відновлюваній енергетиці, збереженню довкілля та екологічно чистому розвитку електроенергетики. Стимули, які були впроваджені для підтримки розвитку ВДЕ (зокрема, «зелені» тарифи), на жаль, здобули в суспільстві негативного іміджу.

Введення Законом № 810-IX знижувальних коефіцієнтів для ставок тарифів на вироблену ВДЕ електричну енергію викликає багато питань. 
Вказана обставина викличе сумніви в інвесторів у надійності інвестицій в Україні та, як наслідок, зниження обсягів інвестування або повернення інвестицій. Так, у 2020 році сталося зниження рівня інвестицій у ВДЕ на $68 \%$.

На це є декілька причин. Зокрема, незрілість нового ринку електричної енергії, непродумані рішення органів влади й тиск з боку традиційної енергетики та великих промислових споживачів електроенергії. Також весь 2020 рік пройшов без проведення заходів в системі «зелених» аукціонів.

\section{Ставки «зелених» тарифів в Україні.}

Ставки «зелених» тарифів на електричну енергію для суб'єктів господарювання встановлюються у гривнях на наступний квартал, 3 урахуванням середнього офіційного курсу гривні щодо курсу євро, встановленого Національним банком України за останні 30 календарних днів, що передують даті останнього засідання НКРЕКП у поточному кварталі року.

Схема запровадження «зеленого» тарифу в Україні наведена на рис. 4 (Джерело: Аналітичний портал «Слово і діло» [9]).

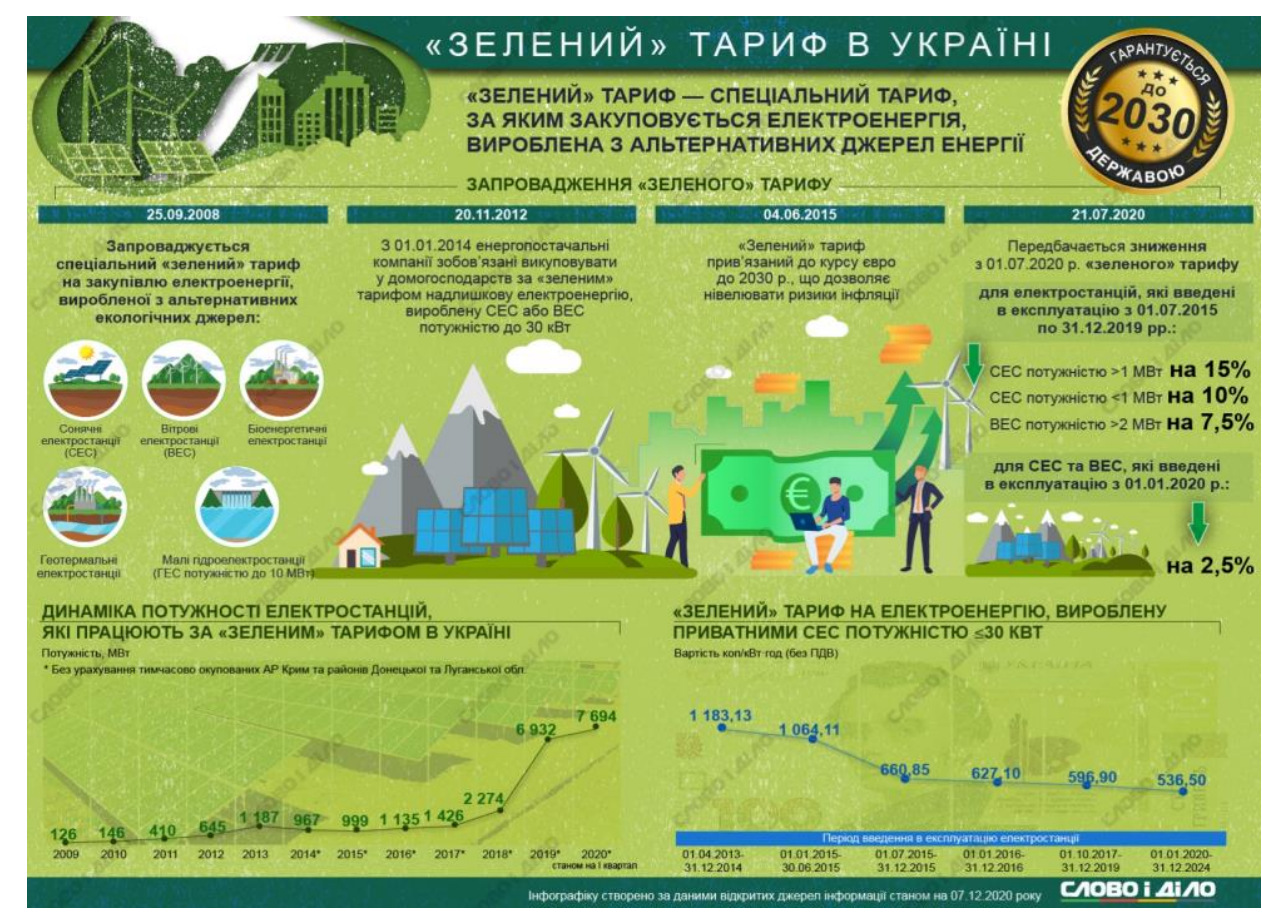

Рис. 4. Схема змін «зеленого» тарифу й темпи росту потужностей ВДЕ

Fig. 4. The scheme of changes in the «green» tariff and the growth rate of RES capacity

Чинні ставки «зелених» тарифів за типами суб'єктів, які визначені 3 урахуванням знижувальних коефіцієнтів згідно з Законом України № 810-IX, наведені у табл. 1.

При розгляді зазначеної таблиці треба враховувати такі обставини:

-ставки «зелених» тарифів для об'єктів ВЕС потужністю більше 5 МВт, які введені в експлуатацію 31 січня 2020 року, на даний час не діють; -ставки «зелених» тарифів для наземних об’єктів СЕС потужністю 1-75,0 МВт на 20202021 роки вказані за умови, що ці об’єкти вже отримали необхідні дозвільні документи на будівництво;

-ставки «зелених» тарифів для наземних об'єктів СЕС потужністю 1-75,0 МВт та більшої потужності на 2022-2029 роки вказані виключно для порівняння 3 аукціонною ціною та на даний час не діють. 
Таблиця 1. Чинні ставки «зелених» тарифів

Table 1. Current rates of «green» tariffs

\begin{tabular}{|c|c|c|c|c|c|c|c|c|c|}
\hline \multirow{2}{*}{$\begin{array}{c}\text { Тип } \\
\text { об’єкту }\end{array}$} & \multirow{2}{*}{$\begin{array}{c}\text { Потужність, } \\
\text { МВт }\end{array}$} & \multicolumn{8}{|c|}{ Дата введення об’єкта в експлуатацію } \\
\hline & & $\begin{array}{l}1.01 .17- \\
31.12 .19\end{array}$ & $\begin{array}{l}1.01 .20- \\
31.10 .20\end{array}$ & $\begin{array}{l}1.11 .20- \\
31.12 .20\end{array}$ & $\begin{array}{l}1.01 .21- \\
31.03 .21\end{array}$ & $\begin{array}{l}1.04 .21- \\
31.12 .21\end{array}$ & $\begin{array}{l}1.01 .22- \\
31.12 .22\end{array}$ & $\begin{array}{l}1.01 .23- \\
31.12 .24\end{array}$ & $\begin{array}{l}1.01 .25- \\
31.12 .29\end{array}$ \\
\hline \multirow{3}{*}{$\mathrm{BEC}$} & $<0,6$ & 5,38 & 5,04 & 5,04 & 4,94 & 4,94 & 4,83 & 4,78 & 4,41 \\
\hline & $0,6-2,0$ & 6,28 & 5,88 & 5,88 & 5,78 & 5,78 & 5,67 & 5,57 & 5,15 \\
\hline & $>2,0^{*}$ & 9,41 & \multicolumn{6}{|c|}{8,82} & 7,72 \\
\hline \multirow{4}{*}{$\begin{array}{c}\text { Наземні } \\
\text { CEC }\end{array}$} & $<1,0$ & 13,90 & 10,97 & 10,97 & 10,61 & 10,61 & 10,24 & 9,87 & 9,50 \\
\hline & $\geq 1,0$ & 12,77 & 10,97 & & & & & & \\
\hline & $1-75,0$ & & & 7,88 & 7,61 & 4,35 & $4,20 * *$ & $4,05 * *$ & $3,9 * *$ \\
\hline & $>75,0$ & & & 4,45 & 4,35 & 4,35 & $4,20 * *$ & $4,05 * *$ & $3,9 * *$ \\
\hline $\begin{array}{c}\text { Дахові і } \\
\text { фасадні } \\
\text { CEC }\end{array}$ & & 16,37 & 12,88 & 11,85 & 11,85 & 11,47 & 11,47 & 11,04 & 10,66 \\
\hline $\begin{array}{l}\text { Приватні } \\
\text { CEC }\end{array}$ & $<0,030$ & 18,00 & 18,00 & 18,00 & \multicolumn{4}{|c|}{16,30} & 14,15 \\
\hline Біомаса & & \multicolumn{8}{|c|}{$12,39 * * *$} \\
\hline Біогаз & & \multicolumn{8}{|c|}{$12,39 * * *$} \\
\hline \multirow{3}{*}{$\begin{array}{l}\text { Малі } \\
\text { ГЕС }\end{array}$} & $<0,2$ & 17,45 & \multicolumn{6}{|c|}{15,73} & 13,95 \\
\hline & $0,2-1,0$ & 13,95 & \multicolumn{6}{|c|}{12,55} & 11,15 \\
\hline & $1,0-10,0$ & 10,45 & \multicolumn{6}{|c|}{9,42} & 8,35 \\
\hline $\begin{array}{c}\text { Геотер- } \\
\text { мальні }\end{array}$ & & 15,02 & \multicolumn{6}{|c|}{13,52} & 12,01 \\
\hline
\end{tabular}

Примітки:

*ВЕС потужністю більше 5 МВт введені в експлуатацію з 1 січня 2020 року зобов’язані брати участь в аукціоні;

** довідково;

*** початок експлуатації до 01.01.23.

Виплата боргів за вироблену «зелену» електроенергію. 10 березня 2021 року представники іноземних інвесторів написали лист президенту України В. Зеленському з проханням втрутитися в ситуацію з ігноруванням органами виконавчої влади умов Меморандуму від 10 червня 2020 року щодо відновлюваної енергетики, оскільки Кабінет міністрів порушує графік виплати боргів за вироблену в 2020 році «зелену» електроенергію. Інвестори в ВДЕ очікували, що держава виконає свої зобов'язання і до кінця 2020 року сплатить $40 \%$ «старого» боргу (9 млрд грн), однак цього не сталося. Станом на 15 березня сплачено лише 3 млрд гривень «старого» боргу.
Крім того, інвестори не бачать жодних рішень Кабміну щодо сплати інших боргів в обсязі 13,4 млрд грн протягом поточного року.

В статті «Як криза на ринку електроенергії прикривається зеленим тарифом» [10] А. Конеченков (Голова правління УВЕА) пропонує обмежити ручне керування ринком, яке в переважній більшості випадків працює не на користь державі, а на задоволення інтересів окремих осіб. «Сьогодні винним за енергетичну кризу намагаються зробити «зелений» тариф, який практично демонізується опонентами зеленої енергетики. На їхній погляд, даний механізм підтримки відновлюваної енергетики є 
причиною i нестабільної роботи ринку, i національному ринку електроенергії $\epsilon$ підвищення тарифів для населення, і кризи на неправильна стратегія продажу виробленої енергії ринку електроенергії загалом. та неефективна робота самого ринку».

Але частка ВДЕ у 2020 році 7,3\% в Інформація Державного підприємства загальному обсязі генерації не може так впливати «Гарантований покупець» щодо розрахунків 3 на ситуацію в сфері електроенергетики. виробниками електроенергії з ВДЕ [11] надана Незалежно від розміру «зеленого» тарифу, на рис. 5. (Джерело: Державне підприємство причиною заборгованості та кризи на «Гарантований покупещь»).

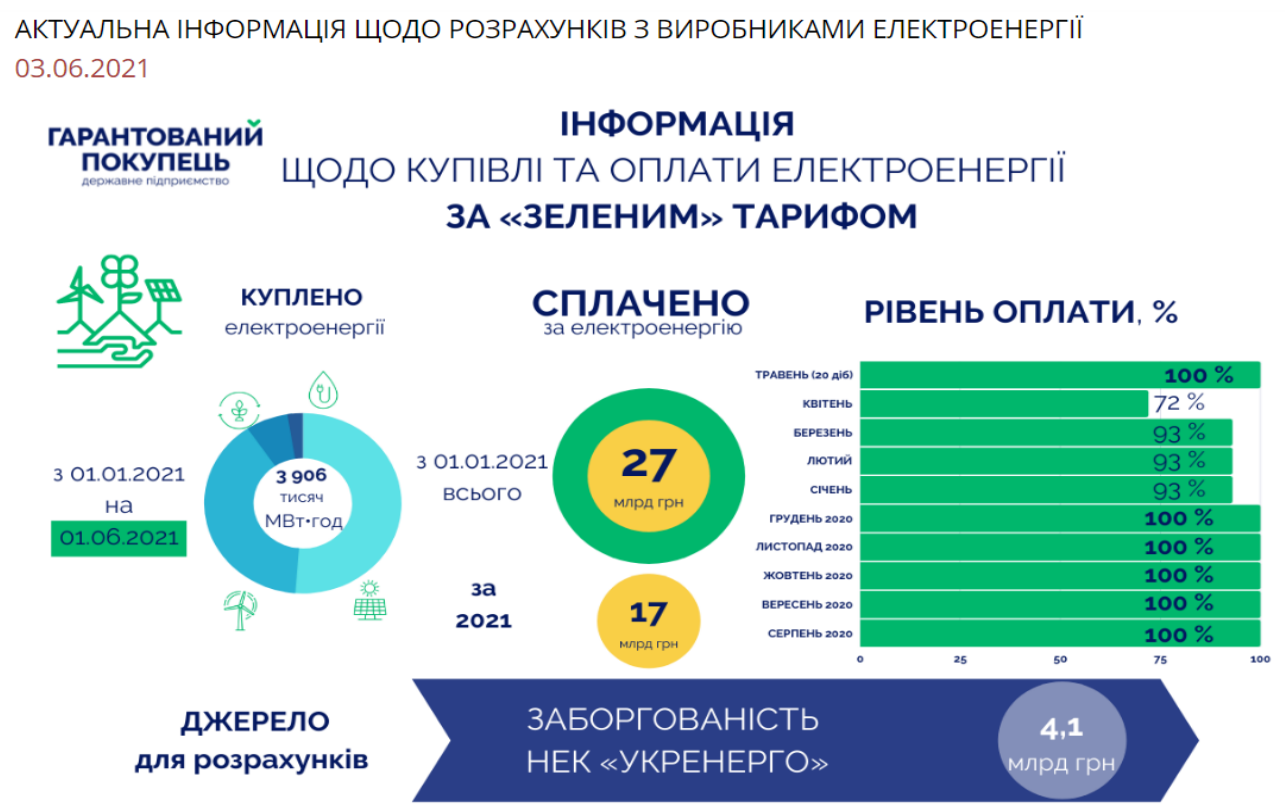

Рис. 5. Актуальна інформація Державного підприсмства «Гарантований покупець»

Fig. 5. Current information of the State Enterprise «Guaranteed Buyer»

\section{Огляд перспективних механізмів} підтримки розвитку ВДЕ. Громадська організація «Центр екологічних ініціатив «Екодія» у дослідженні «Україна після «зеленого» тарифу» [12] позначила декілька перспективних механізмів підтримки розвитку відновлюваної енергетики у межах нової моделі ринку електроенергії України:

\section{Корпоративні договори купівлі-продажу}

енергії. Корпоративні договори купівлі-продажу енергії (РРА) - це довгострокові договори купівліпродажу електричної енергії з ВДЕ, відповідно до яких покупцем електричної енергії виступає не визначене державою підприємство (як наразі в
Україні ДП «Гарантований покупець»), а приватні компанії.

«Зелені» надбавки. У межах цього механізму виробники енергії з ВДЕ продають їі на ринку за загальними правилами, але додатково отримують надбавку за кожну продану кіловатгодину. «Зелена» надбавка може бути фіксованою або динамічною.

Контракти на різницю. За механізмом «контракт на різницю» виробники «зеленої» електроенергії продають іiі за ринковими цінами, але також укладають 3 державою або іншими організаціями додатковий договір. Відповідно до нього вони будуть або отримувати компенсацію, 
яка складається 3 різниці між зафіксованим тарифом і реальною ціною продажу на ринку, або навпаки - оплачувати цю різницю іншій стороні.

Висновки. Розвиток відновлюваної енергетики сприяє енергетичній незалежності держави, яка $є$ складовою національної безпеки України. Наразі в сфері відновлюваної енергетики України вводиться система аукціонів, яка у світі є одним 3 найбільш широко розповсюджених інструментів енергетичного переходу. Згідно 3 чинним законодавством, у 2020 році знижено ставки «зеленого» тарифу для новозбудованих об'єктів ВДЕ, а також встановлено ретроспективне зниження ставок для діючих електростанцій, яким тариф було встановлено раніше. Проведення перших (пілотних) аукціонів 3 розподілу квот підтримки ВДЕ планується у 2021 році. В межах нової моделі ринку електроенергії України, окрім аукціонів, можуть використовуватися інші механізми підтримки відновлюваної енергетики.

1. Закон України «Про альтернативні джерела енергії». [Електронний ресурс].

URL: https://zakon.rada.gov.ua/laws/show/555-15\#Text.

(дата звернення: 22.06.2021).

2. Закон України «Про внесення змін до деяких законів України щодо встановлення «зеленого» тарифу». [Електронний ресурс].

URL: https://zakon.rada.gov.ua/laws/show/601-17\#Text. (дата звернення: 22.06.2021).

3. Закон України «Про внесення змін до деяких законів України щодо забезпечення конкурентних умов виробництва електроенергії 3 альтернативних джерел енергіï». URL: https://zakon.rada.gov.ua/laws/show/514-19\#Text. (дата звернення: 22.06.2021).

4. Закон України «Про ринок електричної енергії». URL: https://zakon.rada.gov.ua/laws/show/2019-19\#Text. (дата звернення: 22.06.2021).

5. Закон України «Про внесення змін до деяких законів України щодо забезпечення конкурентних умов виробництва електричної енергії з альтернативних джерел енергії». [Електроннийресурc]. URL: https://zakon.rada.gov.ua/laws/show/271219\#Техt (дата звернення: 22.06.2021).

6. Постанова НКРЕКП від 26.04.2019 № 641 «Про затвердження нормативно-правових актів, що регулюють діяльність гарантованого покупця та купівлі електричної енергії за «зеленим» тарифом та за аукціонною ціною». [Електронний ресурc]. URL: https://zakon.rada.gov.ua/laws/show/v0641 874-19\#Техt (дата звернення: 22.06.2021).

7. Минэнерго настроено проводить «зеленые» аукционы в 2022 году и пересмотреть квоты на участие в них - глава УВЭА. [Електронний ресурс].

URL: https://interfax.com.ua/news/greendeal/750892.html. (дата звернення: 22.06.2021).

8. Закон України «Про внесення змін до деяких законів України щодо удосконалення умов підтримки виробництва електричної енергії з альтернативних джерел енергії». [Електронний ресурc]. URL: https://zakon.rada.gov.ua/l aws/show/810-20\#Tеxt (дата звернення: 22.06.2021).

9. Схема змін «зеленого» тарифу та темпи росту потужностей ВДЕ. [Електронний ресурc]. URL: https://www. slovoidilo.ua/2020/12/07/infografika/ekonomika/zelenyj-taryf-

ukrayini-tempy-zrostannya-potuzhnostej-vyrobnykivvidnovlyuvanyx-dzherel-enerhiyi.

(дата звернення: 22.06.2021).

10. Як криза на ринку електроенергії прикривається зеленим тарифом. [Електронний ресурс].

URL: https://nv.ua/ukr/biz/experts/problemi-rinka-elektroenergijichomu-zeleniy-tarif-ne-prichina-novini-ukrajini-

50153574.html?fbclid=IwAR0Kqm5tGm1mHu4yDzO5Jv5i7AIwd4 ADSa0gM3BjEy_RyI1X7CDmtMuYDOc.

(дата звернення: 22.06.2021).

11. Актуальна інформація щодо розрахунків 3 виробниками електроенергії. [Електронний ресурс].

URL: https://www.gpee.com.ua/main/news?id=342. (дата звернення: 22.06.2021).

12. «Україна після «зеленого» тарифу». [Електронний ресурc]. URL: https://ecoaction.org.ua/alternatyv y-zt.html. (дата звернення: 22.06.2021).

\section{REFERENCES}

1. Zakon Ukrayiny "Pro alternatyvni dzherela energiyi". [Law of Ukraine “On Alternative Energy Sources”]. [Electronic resource]. URL: https://zakon.rada.gov.ua/laws/show/55515\#Text. (Applying date: 22.06.2021). [in Ukrainian]. 
2. Zakon Ukrayiny "Pro vnesennya zmin do deyakyx zakoniv Ukrayiny shhodo vstanovlennya "zelenogo" taryfu". [Law of Ukraine "On Amendments to Certain Laws of Ukraine Concerning the Establishment of a "Green" Tariff]. [Electronic resource]. URL: https://zakon.rada.gov.ua/laws/show/60117\#Text. (Applying date: 22.06.2021). [in Ukrainian].

3. Zakon Ukrayiny "Pro vnesennya zmin do deyakyx zakoniv Ukrayiny shhodo zabezpechennya konkurentnyx umov vyrobnycztva elektroenergiyi z alternatyvnyx dzherel energiyi”. [Law of Ukraine "On Amendments to Certain Laws of Ukraine on Ensuring Competitive Conditions for Production of Electricity from Alternative Energy Sources"]. [Electronic resource]. URL: https://zakon.rada.gov.ua/laws/show/514-19\#Text. (Applying date: 22.06.2021). [in Ukrainian].

4. Zakon Ukrayiny "Pro rynok elektrychnoyi energiyi". [Law of Ukraine "On the electricity market"]. [Electronic resource]. URL: https://zakon.rada.gov.ua/laws/show/201919\#Text. (Applying date: 22.06.2021). [in Ukrainian].

5. Zakon Ukrayiny "Pro vnesennya zmin do deyakyx zakoniv Ukrayiny shhodo zabezpechennya konkurentnyx umov vyrobnycztva elektroenergiyi z alternatyvnyx dzherel energiyi”. [Law of Ukraine "On Amendments to Certain Laws of Ukraine on Ensuring Competitive Conditions for Production of Electricity from Alternative Energy Sources"]. [Electronic resource]. URL: https://zakon.rada.gov.ua/laws/show/2712-19\#Text. (Applying date: 22.06.2021). [in Ukrainian].

6. Postanova NKREKP vid 26.04.2019 No. 641 "Pro zatverdzhennya normatyvno-pravovyx aktiv, shho re-gulyuyut diyalnist garantovanogo pokupcya ta kupivli elektrychnoyi energiyi za "zelenym" taryfom ta za aukcionnoyu cinoyu». [Resolution of the National Commission for Regulation of Economic Competition dated April 26, 2019 No. 641 "On approval of regulations governing the activities of the guaranteed buyer and purchase of electricity at the" green "tariff and at the auction price"]. [Electronic resource]. URL: https://zakon.rada.gov.ua/laws/show/v0641874-19\#Text. (Applying date: 22.06.2021). [in Ukrainian].

7. Minenergo nastroyeno provodit "zelenyye" auktsiony v 2022 godu i peresmotret kvoty na uchastiye v nikh - glava UVEA.
[The Ministry of Energy is set to hold "green" auctions in 2022 and revise the quotas for participation in them - the head of the UWEA]. [Electronic resource]. URL: https://interfax.com.ua/ne ws/greendeal/750892.html. (Applying date: 22.06.2021). [in Russian].

8. Zakon Ukrayiny "Pro vnesennya zmin do deyakyx zakoniv Ukrayiny shhodo udoskonalennya umov pidtrymky vyrobnycztva elektrychnoyi energiyi z alternatyvnyx dzherel energiyi”. [Law of Ukraine "On Amendments to Certain Laws of Ukraine on Improving the Conditions for Supporting the Production of Electricity from Alternative Energy Sources"]. [Electronic resource]. URL: https://zakon.rada.gov.ua/laws/show 1810-20\#Text. (Applying date: 22.06.2021). [in Ukrainian].

9. Sxema zmin "zelenogo" taryfu ta tempy rostu potuzhnostej VDE. [The scheme of changes in the "green" tariff and the growth rate of RES capacity]. [Electronic resource]. URL: https://www.slovoidilo.ua/2020/12/07/infografika/ekonom ika/zelenyj-taryf-ukrayini-tempy-zrostannya-potuzhnostejvyrobnykiv-vidnovlyuvanyx-dzherel-enerhiyi. (Applying date: 22.06.2021). [in Ukrainian].

10. Yak kryza na rynku elektroenergiyi prykryvayetsya zelenym taryfom. [As the crisis in the electricity market is covered by a green tariff]. [Electronic resource].

URL: https://nv.ua/ukr/biz/experts/problemi-rinkaelektroenergiji-chomu-zeleniy-tarif-ne-prichina-novini-ukrajini50153574.html?fbclid=IwAR0Kqm5tGm1 mHu4yDzO5Jv5i7AI wd4ADSa0gM3BjEy_RyI1X7CDmtMuYDOc (Applying date: 22.06.2021). [in Ukrainian].

11. Aktualna informaciya shhodo rozraxunkiv $\mathrm{z}$ vyrobnykamy elektroenergiyi. [Up-to-date information on settlements with electricity producers]. [Electronic resource]. URL: https://www.gpee.com.ua/main/news?id=342

(Applying date: 22.06.2021). [in Ukrainian].

12. "Ukrayina pislya "zelenogo" taryfu". ["Ukraine after the "green" tariff]. [Electronic resource]. URL: https://ecoaction.org.ua/alternatyvy-zt.html (Applying date: 22.06.2021). [in Ukrainian].

Стаття надійшла до редакції 05.07.21 Остаточна версія 20.09.21 